\title{
Harbingers of feminism? Gender, cultural capital and education in mid-twentieth-century rural Wales
}

\author{
Sally Baker ${ }^{\mathrm{a} *}$ and Brian Brown ${ }^{\mathrm{b}}$ \\ ${ }^{a}$ School of Social Sciences, Bangor University, Bangor, Wales; ${ }^{b}$ Faculty of Health and Life \\ Sciences, De Montfort University, Leicester, UK
}

\begin{abstract}
This paper reports the results of a small-scale narrative study of men and women who grew up in mid-twentieth-century rural Wales, and their reminiscences regarding women and education. Although the dominant image of Wales during that era is that of a male-dominated society, all of our participants remembered influential independent women and educational aspiration for both girls and boys. We use Bourdieusian notions of types of cultural capital and the role of women in transmitting this to illuminate our participants' narratives. Accounts of family life disclosed themes of sacrifice concerning education, poverty during childhood and the role of school teaching as a career for women. Yet at the same time, there were forms of exclusion in operation. In conclusion, we suggest that in many ways, the women remembered by our participants could be seen as forerunners of the second wave of feminism.
\end{abstract}

Keywords: Wales; women; cultural capital; education; aspiration

\section{Introduction}

This paper explores gender issues that influenced the education of a small group of people who grew up in Welsh-speaking communities in rural Wales in the post-war years. It grew from a wider study looking at peoples' experience of education in Welsh-language communities. It was clear from this that gender pervaded the accounts of both men and women, and their descriptions provided a rich data set relating to gender over a period of time stretching back to the early years of the twentieth century.

Most scholarship on Wales in the twentieth century describes a strongly patriarchal nation. The traditional industries and forms of employment upon which the economy rested were very male-dominated, such as quarrying, mining and agriculture. Historical accounts have described the marginalisation and low status ascribed to women. For example, Jones (1982) describes the way in which there was no role at all for women in the slate quarry and the low status that the women in quarrying communities had in the eyes of other people in the locality. Post-war community studies of Wales (Frankenberg 1957; Emmett 1964; Davies and Rees 1960) tell us little about women other than their activities in the domestic sphere - or en masse, for example in the Women's Institute, or in the occasional specific social role, such as that of 'nurse'. Rosser and Harris's (1965) study of familial relationships in Swansea reveals women

*Corresponding author. Email: sos806@bangor.ac.uk 
beginning to break out of the domestic sphere after generations of being located in that position. More recent literature suggests that women in Wales are 'behind' women in England in the world of work and even feminist activities (Beddoe 2000; Holloway and Kneafsey 2004).

Yet some lesser-known accounts suggest a hitherto under-explored radicalism and an early activism - women played a key role in the Welsh language society, Cymdeithas Yr Iaith Gymraeg, and many were leading figures. Women have been prominent in the Welsh nationalist party Plaid Cymru, although there is conflicting opinion as to their degree of influence (Watson 1990; Charles and Hughes-Freeland 1995). More recent activism in Wales, such as the 1984-1985 miners' strike, saw women take a very high profile (Miller 1986). Many 'miners' wives' themselves stated that their actions in the strike changed their lives: it drew them into work, education and activism (Seddon 1986; Stead 1987). In the light of all these strands of evidence, some scholars have now begun to piece together the stories of activism and women's liberation in Wales through the latter half of the twentieth century (Beddoe 2000; Rolph 2002).

There are still some areas that have been under-explored which, we would argue, are crucial to making sense of the subsequent social movements in the 1970s that became known as 'second-wave' feminism. These did not colonise virgin territory, but gained a foothold precisely because the ground had somehow already been prepared. There is little scholarship regarding girls' and women's relationship to education in Wales or Welsh-speaking communities, although Wales traditionally had many women school teachers and Sunday school teachers. Many of these may only have had a basic level of education themselves, but were relatively well-educated compared to other members of the community, especially the children, and were crucial in educating others. When the University of Wales, Bangor was first established (as the University College of North Wales) in 1884, a third of its students were female (Williams 1985), a high proportion for that era. There is a tradition of Welsh women literati, such as Kate Roberts (1891-1985) who sought to depict the hardships of life for women in the quarrying neighbourhoods of North Wales in fiction such as Feet in Chains (Roberts 1980).

In the British Isles, religious nonconformity, permitted since the 1689 Toleration Act, led to the open development of many differently inflected variants of Christianity. The major events shaping religious belief and observance in Wales came with the advent of Methodism in the eighteenth century. In Wales, this involved some notable women such as Anne Griffiths (1776-1805). This movement, punctuated by periodic 'revivals', held a firm grip on Wales until the mid-twentieth century. Teenage girls were recorded as being some of the most charismatic preachers in the 1903-1904 religious revival (Orr 1975; Whittaker 1984), although the dominant images of educated or cultured people have been male. It is only in the twenty-first century that women such as Mererid Hopwood have achieved high honours at Eisteddfodau (EOC Wales 2005). However, it appears that a proportion of women in Wales have been at the forefront of political change, and have been teaching and even preaching, for quite some time.

There is a sizeable body of scholarship on gender influencing education from countries other than Wales. There has been much work done regarding the influence of mothers on the educational aspirations and achievements of both boys and girls (DeGarmo, Forgatch, and Martinez 1999; Schoon and Parsons 2002). There is also much work regarding gendered influence of schoolteachers (Warrington, Younger, 
and Bearne 2006) and the effect of peer pressure, usually that of boys on other boys (Arnot, David, and Weiner 1998; OFSTED 2003). Dyhouse (2002) has documented the role of mothers in the transmission of cultural capital and others, such as Schaller, Rochar, and Barsinger (2007), underscore the value attached by migrant mothers to their children's education, especially when they have had little themselves. Therefore, the recent history of Wales yields some intriguing opportunities to examine the role of women in formulating, reproducing and sustaining culture, while at the same time laying the foundations for significant change.

In order to unpack the enigma of women and their relationship to education in Wales in the mid-twentieth century, the present paper reports the results of a smallscale study of biographical narratives. Participants' accounts suggest that the influence of women on the educational and social ambitions of both men and women who grew up in post-war Welsh-speaking communities was considerable. Participants disclosed the presence of independent, influential women in their families and communities who were a substantial driving force and were in a sense the harbingers of social and cultural changes that were apparent in the 1970s as the 'second wave' of feminism yielded cultural and legislative changes. Middleton (1987) documented a similar process in women who grew up in post-war New Zealand.

In making sense of the situations described by participants, we will draw upon the influential work of Pierre Bourdieu, and in particular his notion of cultural capital (Bourdieu and Passeron 1974; Bourdieu 1986). We use Bourdieusian notions of cultural capital and habitus to illuminate our participants' accounts of the influence of women in what appeared to be a highly patriarchal society.

In Bourdieu's formulation, cultural capital has three differing forms, namely:

(1) An embodied state, including a person's character and way of thinking, formed through socialisation.

(2) An objectified state, including things that are owned, such as scientific instruments or works of art. To gain such cultural assets, one needs to have cultural habitus.

(3) An institutionalised state in the form of educational qualifications.

Their value can be measured in relation to the labour market; but their value may also be more diffuse, in that they may contribute to an accumulated sense of prestige and cultural value. For Bourdieu, educational qualifications represent the 'certificate of cultural competence which confers on its holder a conventional, constant, legally guaranteed value with respect to power' (Bourdieu 1986, 248). Despite hitherto limited applicability to explorations of gender, Bourdieu's insights are increasingly appreciated in examining gender and teacher education (Acker and Dillabough 2007), women as intellectual workers (Eagleton 2005) and the role of examination proficiency as a kind of cultural capital for Victorian schoolgirls (Jacobs 2007).

The idea of incorporating gender into analyses of cultural capital is not necessarily new. Dumais (2002) introduced the idea that gender is crucial in determining the role of cultural capital in increasing educational achievement and shows how gender and social class interact to produce different benefits from cultural capital.

Bourdieu argues that 'the scholastic yield from educational action depends on the cultural capital previously invested by the family' (Bourdieu 1986, 244) and 'the initial accumulation of cultural capital, the precondition for the fast, easy accumulation of every kind of useful cultural capital, starts at the outset, without delay, without 
wasted time, only for the offspring of families endowed with strong cultural capital' (Bourdieu 1986, 246).

Thus, our interest in the educational success of people from North Wales (Baker 2005) prompted a focus on family life and, in line with predictions from the background literature, on the role of mothers in facilitating the preparedness of their offspring for education and how they could be apparently such powerful vectors for this form of capital in circumstances which, on the face of it, might appear far from promising. The Welsh case might furnish examples similar to the cultures of aspiration noted for children by Schaller, Rocha, and Barsinger (2007), and might add to the insight that mothers invest what might be called 'emotional capital' in their children's education (Reay 2000).

Although our study is small-scale, by exploring in detail the narratives of these individuals we also hope to contribute to the kinds of debates prompted by Walkerdine's (e.g. 2003) accounts of social mobility and social class, and how trajectories of 'self help' and 'self improvement' were formulated and sustained. Like Steedman (1986), we try to uncover the 'hidden histories' of women. It also enables us to look at their educational experiences in a broader context and see precursors of major social changes that followed in the next 30 years.

\section{Methodology}

This paper reports the narratives of a study of 10 participants who agreed to be interviewed. In terms of ethnic and cultural heritage, all identified themselves as Welsh, and all had grown up in Welsh-speaking communities. Participants were aged 49-74 years. Some had 'stable' backgrounds with family histories of employment and durable familial relationships, whereas others had experienced negative events in their younger lives. The participants were employed in academia or the professions. As adults, none of the participants could be described as 'marginalised', and had enjoyed middle-class careers. Yet many reported experiencing considerable deprivation when younger, usually rural poverty. Interpreting the backgrounds of some of these participants in terms of social class is problematic. The participants were from Welsh-language communities in Wales, and had thus grown up in a culture rather different from that found elsewhere in the UK. However, as children, all showed features that would be described in England as 'working-class'. Their parents were employed in manual jobs, or were unemployed and living on low incomes. (Two respondents' mothers had trained as teachers, but their fathers were employed in manual work and the household income was low.) The participants were usually the first people in the family to have attended university. They were approached via a snowball sampling technique amongst people already known to the first author, who were asked to introduce other people who might be interested in the study.

A simple table has been constructed, showing the participants' gender, their position in the family, age and their current employment status (Table 1).

The interviews for the present study adopted an open-ended approach that was a modified form of the autobiographical interviewing method of Chamberlayne, Bornat, and Wengraf (2000) and Chamberlayne, Apitzsch, and Bornat (2004), where the researcher begins with a single question and subsequently encourages elaboration. These interviews began with questions about experiences during childhood, the family setting and the immediate cultural and geographical milieux they remembered, and then proceeded with the participant leading, and the interviewer seeking clarification 
Table 1. Participants in the study.

\begin{tabular}{llcl}
\hline Name & Gender and position in family & Age & Employment status \\
\hline Mabon & Male; only child & 49 & Lawyer \\
Gwen & Female; one younger brother & 53 & Teacher trainer \\
Arwel & Male; middle child in family of three sons & 56 & University senior manager \\
Ceinwen & Female; one younger brother & 51 & Academic \\
Eryl & Male; one older sister & 50 & Pharmacist \\
Ifor & Male; position relative to siblings unknown & 67 & Retired academic/author \\
Eifion & Male; only child & 59 & Academic \\
Geraint & Male; one younger sister & 60 & University senior manager \\
Sion & Male; only child & 74 & Retired teacher \\
Myfanwy & Female: position relative to siblings unknown & 59 & Teacher trainer \\
\hline
\end{tabular}

and elaboration, seeking information on their experiences as they grew up and focusing attention on what they remembered about the roles of men and women, the place of education and learning, the role of community and religious organisations, and the experience of family life.

The analysis proceeded in line with Chamberlayne, Bornat, and Wengraf's (2000) recommendations by discussion of the interviews on a case-by-case basis, with a view to identifying themes and pivotal moments in the process of growing up and the enactment of gender in participants' earlier lives. The notes and records of these discussions formed a further layer of data that was drawn upon for analysis. The analysis was also informed by the issues raised in the background literature concerning the types of identities, interpretive repertoires and narrative forms that were drawn upon to help understand how gendered identities and life trajectories were constructed and constrained by the participants.

The analytic strategy was at first informed by the insight from previous literature that there might be distinct forms of cultural capital accumulation strategy, or that somehow mothers were able to impress the value of learning or cultural heritage upon the rising generation, in the context provided by the economic and social location of participants. There was also an expectation that education, religious involvement or occupational experiences might play a role in constructing personal identity as a man or woman, and the relationship that cultural capital might have to the development of that identity in terms of added value or credentials gained.

\section{Results and discussion}

The most consistent theme in our results, having the status of a 'core category', concerned the way that our participants remembered educational encouragement and aspiration for both boys and girls. Our study revealed many reminiscences of ambitious mothers. Fathers were often described as supportive, but overall they did not appear to be granted the status of a real driving force. Our participants remembered traditional gender roles in other spheres of life, and some participants explicitly remembered a very male-dominated world beyond the world of education and social ambition. In our presentation of results, we will try to unpick a complex picture where resources of cultural capital intersected with a world otherwise sharply divided along lines of wealth and gender. We use direct quotes from a number of informants, but 
quotes from three of our participants in particular (Mabon, Gwen and Ceinwen) are used, as these respondents talked extensively about the themes discussed in this paper and for which their accounts were particularly apposite.

\section{Educational ambitions and personal sacrifices}

In seeking the origins of these accounts of education being valued, and in attempting to unpack the role of women, one common theme among our informants was that of socially ambitious mothers who had missed out on the education that they had desired and who therefore wanted their children to have that experience. Both men and women had felt this.

Some of the interviewees were acutely aware that they were among the first generation, or often were the first member, of their family to attend university:

Geraint: In some sense, going to college on behalf of the generation previously, who hadn't been able to go to college - you're almost going to college as a proxy for other people... the thought of, for example, failure at university would have been horrendous... you would not be letting yourself down, you'd be letting down a whole generation of people for whom you were there as this proxy.

These people also stressed that previous generations and/or other members of their family had possessed the ability to gain entry to university, but circumstances such as poverty had prevented this:

Ceinwen: My father always said he [his brother] was a brilliant mathematician and it was a crying shame that he'd never had that university education; and the girls of the family as well, they were very, very good mathematically... they were all aware that they'd missed out on that university education... they were keenly aware they'd missed out... I had an uncle... a carpenter by trade, and he never had the opportunity to go to university, in fact he sacrificed that so that his younger sister could go to university.

Here there is a sense that, as a result of financial circumstances, if one family member went to university it meant others could not; as if education was a distinctly finite resource.

In these quotes, the sense of a powerful mixture of emotions being passed down through generations is evident, with some family members feeling enormous pressure to succeed, having achieved the privilege denied to their forebears and being aware that other family members might feel cheated.

This interviewee was one of the first members of the family to go to university and interestingly remembered gender as 'not being an issue'. This was a radical family, involved in industrial action and Welsh politics - it would seem that interest in politics and the fact that 'we were fighting for the language' subsumed gender issues. Although Ceinwen's mother was politically active (and, for a time, was the main wage-earner while her husband took care of the family), Ceinwen does not ever remember her talking about feminism. When asked whether, as a child, she remembered men and women being of equal status, Ceinwen replied: 'Of course. I'm surprised the question would even be asked'. This family was far from patriarchal, but it was an interesting combination of factors that led to the decision that Ceinwen's mother should become the wage-earner. The family became concerned for her father's welfare (although he was in good health) when a close friend was killed underground 
and Ceinwen's mother, as a teacher, could earn a higher salary than her father could as a miner. Ceinwen described her father as 'an excellent cook and far better around the house', her mother being a 'very indifferent housewife'.

Although this family placed great importance on education, it was Ceinwen who went to university, not her younger brother. Her perception was that girls 'are naturally more academic'.

Other interviewees remembered their mothers living out their educational ambitions through their children:

Eryl: My mother had to go working to support - she was one of six and she was the eldest - I reckon she could have gone for further [sic] education, given the opportunity. So that was a major factor, in that my mother wanted us to go to further [sic] education, if at all possible, to make up for what she had to do without.

Thus, there was a sense that the sacrifices that had been made and the opportunities foregone made themselves felt across the generations. Previous literature has demonstrated the importance of parental influence, particularly that of mothers, on their children's educational aspirations.

Dyhouse (2002), while focusing on the middle years of the twentieth century, noted that maternal support and sacrifice was commonly undertaken to assist boys, especially among those from modest backgrounds. This sense of sacrifice is borne out in comments from our participants. Some mothers had missed out themselves and wanted children to have opportunities they had not enjoyed, and were ambitious for both boys and girls. This is also reflected in scholarship focusing on the situation in England. Dyhouse (1995) identifies women as also being ambitious in their roles as teachers, and as influencing boys and girls.

Walkerdine and Lucey (1989) explored at length the way in which mothers of young children nurtured 'educational' development at home, and the notions of 'sensitive' mothering linked to this; and were interested in how such notions resulted in criticism of some working-class mothers. Walkerdine and Lucey were writing about a later generation of mothers and children than our participants, but the parallels of mothers located within the domestic sphere being responsible for and influencing childrens' educational development are obvious.

The discourses of 'missing out', 'sacrifice' and 'poverty' appear to serve important functions in terms of securing the sense that the family has a measure of cultural capital. The lack of formally certified educational qualifications (Bourdieu 1986), in this formulation, is not because of personal failings, stupidity or lack of awareness. It is rather because of other circumstances constituting a force majeure, such as poverty. In a sense, then, it is a way of securing the notion that they had abilities, knowledge and cultural capital that were manifest in family and community life but were merely not apparent in terms of official certifying institutions. This sacrifice, then, is a kind of capital in the form of accumulated labour. In Bourdeiusian terms, we can read this as embodied capital, of value added to the individual or family through labour and through deferred gratification - 'sacrifice', if you will.

\section{Narratives of poverty}

The role of poverty in restricting or truncating educational ambitions for both boys and girls was apparent in the stories participants told about their families. These 
family tales often contained an implicit contrast between the hardship of days gone by with the relative affluence of the present. Most of our participants were in their 50s. This was, of course, the generation who went to university in the 1960s, at a time of educational expansion and when maintenance grants became available. Yet some of our participants talked of their parents and grandparents, indicating how, for some families, the idea of girls (and boys) gaining an education had long been an attractive one and how the accomplishments of both men and women were valued.

Mabon gave a moving, detailed account of the hardship that his mother's family had endured. His mother had been one of five children whose own mother had died when she was young. Her father had lost an arm in the Battle of the Somme:

Mabon: He was a postman, he used to look after them with one arm, he used to dig the garden, plant the veg, so they were a family of very limited means and there were difficulties in pensions... very, very little income... about two bedrooms and they used to share beds... she came out of [secondary school] with about nine equivalents of O-levels... nobody could finance her to go on...

The aftermath of World War I affected other branches of the family, too. Mabon's perception of the situation for the whole generation of his parents' age was that of poverty intersected by traditional gender roles; his aunt had been very able, but 'she married young, but her husband had shell shock. She looked after him, so she couldn't do anything else'. For that generation and previously, 'they survived, they were very poor, they survived; but no more than that... you couldn't go to banks, because there was no security for anyone'.

Despite this severe hardship, however, Mabon's mother seemed to have acquired considerable locally recognised cultural capital by the time she was raising him. He remembers her winning prizes at the Eisteddfodau, being 'first in Wales' in a Bible knowledge quiz and writing plays for the church that were always performed. She was clearly able to transmit this cultural capital to her son, enabling him to succeed academically: 'She would always play an active part in the work which I did, and really she was very good with Welsh and English poetry... and enjoyed looking at what I was doing'. When asked if he thought that her own educational chances would have been different if she had been a boy, Mabon replied: 'I don't think it would have made much difference at that particular time... in that family, it was just the lack of money more than anything else...'.

Thus, from accounts like these we can see, even in the absence of formal educational verification of a person's cultural worth, that there were means of acquiring markers of prestige informally, via competitions, Eisteddfodau and activities within church or chapel, that could confer the 'certification' or legitimation for their talents that was lacking from other sources. Thus the cultural capital present here is perhaps more fully of the objectified kind, in that it is marked with artefacts and objects, the garden that was cultivated, the competitions won, the poetry, the plays enacted, and so on. What is also clear is that this stage or moment in the cultural process subsumes the earlier phase of embodied capital. Presumably the toil involved in cultivation, the labour at mastering poetry, drama or Bible study accumulates an embodied capital too.

\section{Teaching}

An alternative strategy to enhance their stock and standing described by participants from some families, where circumstances permitted, was to enter the teaching 
profession. It has been suggested that there is a feminist subtext to the very history of teacher training in the British Isles, inasmuch as it was one of the earliest careers legitimated for women (Cohee et al. 1998; Hirsch and Hilton 2000). Thus, early in the twentieth century, young women were positioned as playing a key role in the stewardship of educational capital.

The comments from our participants are also consistent with Miles' (1999) observation that mothers were 'moral guides and inculcators of ambition', desiring upward mobility for their sons. This certainly seems to have been true for our male participants, as was Miles' idea that if education could be likened to an infectious disease, 'women have acted as important carriers' (1999, 335). Previously, Jackson and Marsden (1962) wrote about maternal influence in education, highlighting the importance of mother's support for working class entrants of grammar schools. Kelsall, Poole, and Kuhn (1972) stressed the importance of maternal support for higher education for educational success.

Gwen, another participant, remembers hearing about her grandmother's attitude toward her mother when her mother was young: 'It was very strong in my grandmother, she'd felt that my mother and her brother, my uncle, should do very well'. This participant was told by her mother that her grandparents 'had been very, very happy' for her mother to become a teacher. They were 'delighted when she got in'.

But this encouragement of education and careers for girls did not mean that gender roles were absent:

Mabon: As far as girls were concerned, most [of them] really were being geared towards becoming teachers... girls were always thinking of becoming teachers. I don't think they had anything else in their minds.

This observation was supported by Gwen:

Gwen: I didn't consider any other career. I was quite happy. It was what I wanted to do. I think it was always something I wanted to do... it was wanting to do a combination of having the music, of wanting an opportunity to do something that you could have a career at and that would bring you work and bring you a steady wage... it was seen as an acceptable career.

Although it was remembered that both boys and girls were encouraged to become teachers:

Mabon: I don't think any other careers were being advanced basically in the school.

But male and female participants remembered charismatic female teachers influencing them:

Gwen: I think, you know, what will have had a great influence when you're at school is your teachers... absolutely... as a class, we greatly admired our music teacher, and that would have been a tremendous spur for us.

Arwel: $\quad$ Later... in my sixth form... particularly and outstandingly, my English teacher, who really did encourage... the emphasis she put on real intellectual work... she showed enormous confidence in myself...

Nonconformity gripped Wales until relatively recently, and our participants remembered its influence, particularly Sunday school and the Sunday school teachers, who in many people's memories were female: 
Ceinwen: I could read and write before going to primary school. We were taught to read and write in the Sunday school. I remember the old lady with the blackboard and the chalk, and we were taught the alphabet. I vividly remember the first lesson. doing the letter A...

Gwen: I've nothing to back it up, but my impression is that it [the influence] would have been women. My own days, I think it was women. [The sol fah system] ....is a strong influence in lots of Welsh communities, you can sing great works by Mozart or Handel because they've been transcribed into the sol fah notation... it's embedded in some communities still... so there was an influence and education going on there...

Gwen remembered her mother talking of her love of Sunday school as well:

My mother was saying that about when she was a child... Sunday school was an important part of their life... the place where you could hear stories... she really looked forward to that, having something fresh and new to read.

Throughout these quotations, we can see the substantive role accorded to women in teaching, both informally in Sunday schools and formally in school teaching. Once again, we see here that there were women in positions of influence (at least where children were concerned), passing on cultural capital to the next generation of people living in communities that were often seriously disadvantaged.

Teaching was, in a sense, a means by which value was put back into the community by a largely female, educated labour force:

Mabon: They would go to college and lots of them would go to Bangor... so they would go there and they would try and find a job locally... perhaps because they were very Welsh-speaking... I don't think many would have thought of going away to work, always with the intention of coming back to your area.

This was also supported by the benefits that would accrue to the individual teacher too, assisting with the support of the family:

Mabon: [Teaching] was a job for life, it was paid very well at that time.

A further intersection between teaching and valued community activities came with the work ethic that was a part of the Nonconformist identity:

Gwen: $\quad$ Mother was a primary teacher - the idea of education and a strong work ethic, I think, was instilled into us from a very early age.

And:

This had been instilled into them as well, to get on, to work hard and to make a better life for yourself really. They [the women] were quite strong.

Teaching provides a key to understanding how the roads through gender inequality were made at a time when these were not necessarily readily accomplished in other walks of life.

The movement that has been termed 'the feminisation of education' (Francis 2000; Arnot, David, and Weiner 1999) seems to have begun much earlier in our participants' communities than in the British Isles as a whole, inasmuch as it opened up possibilities for personal and familial advancement. Women who taught in the locality from which 
they originated may not have been stepping out of woman's traditional role, but they were afforded an arena in which they could legitimately and profitably deploy the acquisition and exercise of cultural capital.

In the light of this role played by education and teaching in the acquisition of institutionalised cultural capital and career opportunities of women, it is less surprising that girls' achievement was so encouraged. Our female informants all remembered that their mothers were ambitious for them. Whereas encouragement to succeed educationally was offered to both boys and girls, it was widely remembered to come particularly from mothers:

Arwel: $\quad$ I don't think I grew up taking in with my mother's milk some idea that I should go to university. What I did take in virtually with my mother's milk was this sort of tremendous aspiration she had that one should 'do well' at exams... there was great pressure on me from my mother to do well... psychological pressure.

Gwen: We were encouraged to do our best and to aim high; that came through my mother particularly... she would have been the driving force behind that.

Eryl: Definitely, my mother was a driving force... We never discussed it, going to university, but there was positive pressure to do well at school.

The opportunity to attend university and the possibility of entering the teaching profession involves a step from embodied or objectified cultural capital to the fully institutionalised version. Here, we see the full significance of educational qualifications that 'matter' in the wider world, which are sanctioned by legal guarantee, formally independent of the person of the bearer. 'One sees clearly', says Bourdieu, 'the performative magic of the power of instituting, the power to show forth and secure belief, or, in a word, to impose recognition' $(1997,51)$.

Although the present study only refers to only 10 people, in contrast to much prior research, a distinctive feature of these accounts was that the sense of ambition for children to acquire cultural capital was believed to have been relatively equal for both genders:

Interviewer: Would your mum have been as ambitious for you if you'd been a girl?

Mabon: I think so, yes. I think the same would have applied, because she wanted me to have the opportunities that she didn't.

The message from these participants was uncompromising: there was real encouragement for girls, as well as boys, to gain an education. Of course, there are other factors within families that result in educational encouragement for particular children, such as their position relative to other siblings. Yet our participants' narratives were littered with references to educational encouragement and achievement for girls and women, both in various generations of their own families and in the communities around them.

We did wonder whether perhaps these girls were being encouraged by their ambitious mothers with a view to the girls 'marrying well'. Yet our participants could not remember such an attitude prevailing:

Ceinwen: No, it was education for education's sake.

Mabon: I don't think there was that attitude... but maybe if you were living in Bangor or a bigger town than P... [small Anglesey village], which was just a small village, that might be different... but certainly I think, in the countryside, I don't think that was ever the case. 
On meeting a man:

Gwen: I never picked that one up at all - it was just to have a career, to do the best you could.

In the light of demonstrable occupational and educational inequalities in developed nations through the twentieth century and the relatively small proportion of women at university during much of that time (Martin and Goodman 2004; Soloman 1985), the sense of girls being encouraged to achieve might appear unusual. Listening to these memories, one obviously speculates as to how much influence women had in the community. These participants remembered highly influential mothers, grandmothers and aunts, but they also spoke of other women who influenced them educationally schoolteachers and Sunday school teachers. These figures are reminiscent of the stereotypical Welsh 'mam', powerful but located within the domestic sphere, described in novels by writers such as Llewellyn (1951) and mentioned in Raymond Williams's biography (1979).

\section{Power, patriarchy and forms of exclusion}

In counterpoint to this theme of women undertaking - or aspiring to attain - teaching roles, two male participants remembered overtly powerful male head teachers:

Geraint: The head teacher would really decide for you... in a sense, he would have denied access if he thought that someone wasn't suitable. The headmaster told you what you would do: 'Maths is your poison'. And that was my careers advice.

Arwel: $\quad$ The headmaster... moved me up a year [at primary school]... it may well have been really quite important... I probably found that very challenging and I probably reacted very well to that... so a teacher, at a very young age, I think was quite important as well.

There was disagreement among our participants as to whether Wales at that time was controlled by men or not. Mabon was adamant that it was; that men controlled family finances, and that although the church 'would not have survived without them', women had no influence in church matters. Unusually, his family were Anglican rather than belonging to a Nonconformist chapel. Mabon believed that a change in attitude towards women only occurred in the 1960s and 1970s among schools as employers. Before that:

Mabon: You only had the primary schools... you had the headmaster, who was male; all the other teachers were female.

But then:

Mabon: As far as schools were concerned, they were starting to change in the 60 s and 70 s and I think they did change during that period, but elsewhere I think it was very male-dominated.

Yet Gwen and Ceinwen disagreed. Gwen believed that in the chapel, as in other areas of life, men 'fronted', but behind the scenes women had plenty of influence. Ceinwen never for a moment doubted that women were of equal status, but made it clear that 
her family were political radicals and members of a Congregationalist chapel, with an emphasis on equity. In some ways, Ceinwen's family lived feminism before the second wave of feminism was debated. In 1964 her father gave up work as a miner and looked after the family, so that his wife could work full-time. She had been a town councillor, campaigning on issues that feminists later became concerned with, such as childbirth conditions, help for single women with children, and housing. Ceinwen did remember gender restrictions in wider society, though, mentioning that one Welsh county that they had lived in was 'incredibly sexist' because it would not employ married women as secondary teachers. But then Ceinwen's family 'did what we wanted', were proud of their radicalism, associated with other radicals, and clearly had confidence in their own ideals and values.

The presence of powerful women under patriarchal systems is not unusual, although such women are usually only powerful within certain spheres defined by men. The reminiscences of our participants clearly suggest that in rural Wales, women were able to gain strength and power in patriarchal systems, especially in spheres predefined for them by that patriarchal culture. Yet their powers in turn inform, influence and reproduce the cultures in which they are embedded. Some of the scholarship outlined by Anderson (2004) has underscored the more agentic role of women that is coming to light as historians revisit women's histories in religious communities.

Our participants' view of gendered identity in Wales in the post-war years, and how it was inflected by questions of power and influence, was a complex one. The participants gave some idea of the complexity of their perceptions when they offered their spontaneous views as to why some children were encouraged educationally and others weren't. Mabon suggested that his mother may have been particularly ambitious for him because he was an only child. Gwen wondered whether her educational ambitions had been affected by her position as the eldest child. Mabon wasn't at all sure that his success at school was because he was a boy:

It's very difficult to say... I was being pushed, but maybe I had more ability than some people... my cousin, who was the same age, she had the ability as well and she was progressing through school at the same rate as me.

Mabon proffered some insights into the situation:

I know of other people who had the ability to go forward but who were certainly not being encouraged by their family to do so, and that was maybe because of their family background than anything else. In rural Wales, especially Anglesey or wherever, I think it's more complex. It all depends upon the parents' backgrounds and upbringing as well.

Mabon is alluding to another of the concepts for which Bourdieu is famous, namely that of habitus. This involves 'the disposition to act which individuals acquire in the earliest stages of socialisation and which they consolidate by their subsequent choices in life' (Robbins 1993, 159). The habitus of a person, family or community refers to more than just explicit norms and values, because it is embedded within everyday actions, much of which is subconscious, hence the use of the term 'disposition'. Mabon talked quite extensively about this in his interview, remembering children who 'had ability' but who didn't 'go on' and leave the area, because they came from families where 'they didn't do that'. They found paid work immediately after leaving school because that's 'what they'd always done', in a manner strikingly reminiscent 
of Bourdieu and Passeron (1977) in their account of how some students appeared to be at odds with the ethos of the higher education system.

Lest it be thought that Wales in the middle years of the twentieth century was filled with people assisting each other up the cultural capital ladder, it was clear that some people remembered distinctions being drawn between those who were legitimate recipients of assistance and those who were not. Arwel remembered a certain social prejudice shown by the teachers to many of the children in his school that would not have encouraged educational aspiration or achievement:

Arwel: There was a culture... which did tend to write off a large number of kids... they were seen as a problem.

Thus, taking this reminiscence at face value, there appears to be a mismatch between what Bourdieu would describe as the habitus of the social group to which the children belonged and what has latterly been called the 'institutional habitus' of the education system. Drawing from the work of Thomas (2002), McDonough (1996), Reay (1998) and Reay, David, and Ball (2001), institutional habitus describes 'the impact of a cultural group or social class on an individual' $\mathrm{s}$ behaviour as it is mediated through an organisation' (Reay, David, and Ball 2001, para. 1.3). Bourdieu viewed the education system as the primary means through which class order is maintained. Arwel may have been referring here to some kind of disjuncture between the children's habitus and that of the school: the teachers had identified such a habitus as being problematic. But this disjuncture was not a gendered one; instead, it was seen as having more to do with the cultural discrepancies between some families and children and the education system.

In contrast to the ideas expressed by so many of our participants, one respondent had his own explanation for the whole idea of educationally and intellectually aspiring Welsh people:

Ifor: Even the so-called 'culture' - which is alleged to be high-minded and intellectual - was a rather sad way of trying to escape from the dreadful conditions.

But he did note that:

...there was a sense of aspiration to get out of manual labour, and the same tendency applies throughout Wales.

\section{General discussion}

The results reported here, though they are from a relatively small study in a sparsely populated part of the British Isles, show a number of tendencies that have important historical and theoretical implications. Some features of the culture - and the very fabric of family life itself - seem to have been actively encouraging towards young women to continue their education. This occurred both through encouragement and example.

It is fascinating that these reminiscences of influential women and perceptions came from people who grew up in what has often been chronicled as a very patriarchal society. Despite this, it appears that, in an age before feminism was popularised, women were gaining access to means of accumulating certain kinds of cultural capital. The credit or certification for their efforts that some women achieved, especially 
through school teaching, is set in a political-economic system upon which it was in important senses dependent. Poverty was a constraint; but sometimes it was a spur, in the sense that the relatively 'good' wages in teaching could be a valuable bulwark against starvation. Wales is, in a sense, an understated nation, and women may be seen as an understated social group; and it is the cultural context, in the sociological sense of that term, which helped to sustain those patterns of inequality but at the same time helped lay the groundwork for social change in the later part of the twentieth century. Experience, as Pasteur was alleged to say, favours the mind prepared.

In Bourdieu's original formulation, ideas about different types of capital were developed in order to explain how social stratification systems were preserved and the dominant class-reproduction strategy was legitimised (Adam and Rončević 2003, 159). In the present paper, we have shown how some of our participants' recollections suggest that by assiduous cultivation of cultural capital, by intergenerational nurturance of aspirations, and through social networks (although in many ways limited) that confronted children with experiences of cultural accomplishment, the seeds were sown for a mid-twentieth-century perturbation in gender roles. These domestic, social and occupational changes themselves prefigured the larger and more culturally conspicuous social changes of the 1970s. In an important sense, then, the women that our participants remembered made this latter wave of feminism possible. Though these women might not have described themselves as feminist, many of them could be described as harbingers of the movement that led to gender equality being placed on the national policy agenda.

\section{Acknowledgements}

We would like to thank our participants who gave so generously of their time to tell their stories. We would also like to thank two anonymous reviewers for their extremely helpful suggestions regarding an earlier draft of this paper.

\section{References}

Acker, S., and J. Dillabough. 2007. Women 'learning to labour' in the 'male emporium': Exploring gendered work in teacher education. Gender and Education 19, no. 3: 297-316.

Adam, F., and B. Rončević. 2003. Social capital: Recent debates and research trends. Social Science Information 42, no. 2: 155-83.

Anderson, M.C. 2004. Negotiating patriarchy and power: Women in Christian churches. Journal of Women's History 16, no. 3: 187-96.

Arnot, M., M. David, and G. Weiner. 1999. Closing the gender gap: Postwar education and social change. Cambridge: Polity Press.

Arnot, M., J. Gray, M. James, J. Rudduck, and G. Duveen. 1998. Recent research on gender and educational performance. London: HMSO.

Baker, S. 2005. Like a fish in water: Aspects of the contemporary UK higher education system as intended and as constructed. PhD diss., University of Wales.

Beddoe, D. 2000. Out of the shadows: A history of women in twentieth-century Wales. Cardiff: University of Wales Press.

Bourdieu, P. 1986. The forms of capital. Trans. R. Nice. In Handbook of theory and research for the sociology of education, ed. J.G. Richardson, 241-58. New York: Greenwood.

- 1997. The forms of capital. In Education: Culture, economy, society, ed. A.H. Halsey, 46-58. Oxford: Oxford University Press.

Bourdieu, P., and J.C. Passeron. 1974. Cultural reproduction and social reproduction. In Knowledge, education and cultural change, ed. R.K. Brown, 71-112. London: Tavistock.

_., and J.C. Passeron. 1977. Reproduction in education, society and culture. London and Beverly Hills: Sage Publications. 
Charles, N., and F. Hughes-Freeland. 1995. Practicing feminism. London: Routledge.

Chamberlayne, P., U. Apitzsche, and J. Bornat. 2004. Biographical methods and professional practice: An international perspective. Bristol: The Policy Press.

Chamberlayne, P., J. Bornat, and T. Wengraf. 2000. The turn to biographical methods in social science: Comparative issues and examples. London: Routledge.

Cohee, G.E., E. Daumer, T.D.. Kemp, P.M. Krebs, S.A. Lafky, and S. Runzo. 1998. The feminist teacher anthology: Pedagogies and classroom strategies. New York: Teachers College Press.

Davies, E., and A. Rees. 1960. Welsh rural communities. Cardiff: Cardiff University Press.

DeGarmo, D.S., M.S. Forgatch, and C.R. Martinez. 1999. Parenting of divorced mothers as a link between social status and boys' academic outcomes: Unpacking the effects of socioeconomic status. Child Development 70, no. 5: 1231-45.

Dumais, S. 2002. Cultural capital, gender, and school success: The role of habitus. Sociology of Education 75: 44-68.

Dyhouse, C. 1995. No distinction of sex? Women in British universities, 1870-1939. London: UCL Press.

- 2002. Graduates, mothers and graduate mothers: Family investment in higher education in twentieth-century England. Gender and Education 14, no. 4: 325-36.

Eagleton, M. 2005. Nice work? Representations of the intellectual woman worker. Women's History Review 14, no. 2: 203-22.

Emmett, I. 1964. A North Wales village: A social anthropological study. London: Routledge and Kegan Paul.

Equal Opportunities Commission Wales. 2005. Changing Wales. Cardiff: Equal Opportunities Commission Wales.

Francis, B. 2000. Boys, girls, and achievement: Addressing the classroom issues. London: RoutledgeFalmer.

Frankenberg, R. 1957. Village on the border: A social study of religion, politics and football in a North Wales community. London: Cohen and West.

Hirsch, P., and M. Hilton. 2000. Practical visionaries: Women, education and social progress 1790-1930. London: Longman.

Holloway, L., and M. Kneafsey. 2004. Geographies of rural cultures and societies. Aldershot: Ashgate Publishing Ltd.

Jacobs, A. 2007. Examinations as cultural capital for the Victorian schoolgirl: 'Thinking' with Bourdieu. Women's History Review 16, no. 2: 245-61.

Jackson, B., and D. Marsden. 1962. Education and the working class. London: Routledge and Kegan Paul.

Jones, R.M. 1982. The North Wales quarrymen 1874-1922. Cardiff: University of Wales Press.

Kelsall, R.K., A. Poole, and A. Kuhn, eds. 1972. Graduates: The sociology of an elite. London: Methuen.

Llewellyn, R. 1951. How green was my valley. London: Penguin.

McDonough, P. 1996. Choosing colleges: How social class and schools structure opportunity. New York: State University of New York Press.

Miles, A. 1999. Social mobility in nineteenth and early twentieth century England. Basingstoke: MacMillan.

Martin, J., and J. Goodman. 2004. Women and education, 1800-1980. Basingstoke: Palgrave Macmillan.

Middleton, S. 1987. Schooling and radicalisation: Life histories of New Zealand feminist teachers. British Journal of Sociology of Education 8, no. 2: 169-89.

Miller, J. 1986. You can't kill the spirit: Women in a Welsh mining village. London: Women's Press Ltd.

OFSTED. 2003. Boys' achievement in secondary schools. London: Office for Standards in Education.

Orr, J.E. 1975. The flaming tongue: 1900. Chicago: Moody.

Reay, D. 1998. 'Always knowing' and 'Never being sure': Institutional and familial habituses and higher education choice. Journal of Education Policy 13, no. 4: 519-29.

. 2000. A useful extension of Bourdieu's conceptual framework? Emotional capital as a way of understanding mothers' involvement in their children's education. Sociological Review 48, no. 4: 568-85. 
Reay, D., M. David, and S. Ball. 2001. Making a difference? Institutional habituses and higher education choice. Sociological Research Online 5, no. 4. htttp://www.socresonline. org.uk/5/4/reay.html.

Robbins, D. 1993. The practical importance of Bourdieu's analyses of higher education. Studies in Higher Education 18, no. 2: 151-63.

Roberts, K. 1980. Feet in chains. Trans. John Idris Jones. London: Corgi.

Rolph, A. 2002. Not just the miners' strike: The women's liberation movement in South Wales. Paper presented at the Feminist Seventies Conference, 27 April, York, UK.

Rosser, C., and C. Harris. 1965. The family and social change: A study of family and kinship in a south Wales town. London: Routledge and Kegan Paul.

Schaller, A., L.O. Rocha, and D. Barshinger. 2007. Maternal attitudes and parent education: How immigrant mothers support their child's education despite their own low levels of education. Early Childhood Education Journal 34, no. 5: 351-56.

Schoon, I., and S. Parsons. 2002. Teenage aspirations for future careers and occupational outcomes. Journal of Vocational Behaviour 60, no. 2: 262-88.

Seddon, V. 1986. The cutting edge: Women and the pit strike. London: Lawrence and Wishart.

Soloman, B.M. 1985. In the company of educated women: A history of women and higher education in America. New Haven: Yale University Press.

Stead, J. 1987. Never the same again: Women and the miners' strike 1984-1985. London: The Women's Press.

Steedman, C. 1986. Landscape for a good woman: A story of two lives. London: Virago Press.

Thomas, L. 2002. Student retention in higher education: The role of institutional habitus. Journal of Education Policy 17, no. 4: 423-42.

Walkerdine, V. 2003. Reclassifying upward mobility: Femininity and the neoliberal subject. Gender and Education 15, no. 3: 237-48.

Walkerdine, V., and H. Lucey. 1989. Democracy in the kitchen: Regulating mothers and socialising daughters. London: Virago Press.

Warrington, M., M. Younger, and E. Bearne. 2006. Raising boys' achievements in primary schools: Towards an holistic approach. Maidenhead: Open University Press.

Watson, M. 1990. Contemporary minority nationalism. London: Routledge.

Whittaker, C. 1984. Great revivals. Basingstoke: Marshalls.

Williams, J.G. 1985. The University College of North Wales, foundations 1884-1927. Cardiff: University of Wales Press.

Williams, R. 1979. Politics and letters: Interviews with New Left Review. London: NLB. 